Journal of Interdisciplinary History, XLII: I (Summer, 20I I), 29-52.

Luís Espinha da Silveira, Daniel Alves, Nuno Miguel Lima, Ana Alcântara, Josep Puig

\title{
Population and Railways in Portugal, I80I-I930
}

With a few exceptions, Portuguese historiography has adopted a pessimistic view regarding the contribution of the railways to the development of the country. In fact, available studies emphasize the prevalence of private and foreign interests, as opposed to those of the nation. They also underline the financial burden of railway construction for the state, and the corruption associated with it, as well as the incapacity of the Portuguese economy to supply the capital and industrial goods necessary for the development of the railway network. Recent literature examines the role of the railways in the relocation of industry during the first half of the twentieth century and the link between this new means of transport and the country's urban network, focusing mainly on Lisbon and Oporto. ${ }^{1}$

Luís Espinha da Silveira is Associate Professor, Faculty of Social Sciences and Humanities, New University of Lisbon. He is the author of Território e Poder: Nas Origens do Estado Contemporâneo em Portugal (Cascais, I997); editor of Os Recenseamentos da População Portuguesa de 1801 e 1849: Edição Crítica (Lisbon, 2001).

Daniel Alves is Assistant Professor, Faculty of Social Sciences and Humanities, New University of Lisbon. He is the author of A República atrás do balcão: Os lojistas de Lisboa na fase final da Monarquia (1870-1910) (Lisbon, 2010); "Entre o balcão e a política: os lojistas de Lisboa e o republicanismo (I870-I9I0)," Ler História, LIX (20I0), IOI-I23.

Nuno Miguel Lima is a doctoral student, Faculty of Social Sciences and Humanities, New University of Lisbon. He is the author of Os "Homens Bons" do Liberalismo: Os Maiores Contribuintes de Lisboa (1867-1893) (Lisbon, 2009); "Henry Burnay no contexto das fortunas da Lisboa Oitocentista," Análise Social, XLIV (2009), 565-588.

Ana Alcântara is an MSc student in Geographical Information Systems and Science, ISEGI, New University of Lisbon, and a research assistant, benefiting from a research fellowship [SFRH/BTI/33380/2008] awarded by the Fundação para a Ciência e a Tecnologia within the project (INVENT/OooI/2007).

Josep Puig is a GIS technician and an MSc student, University of Lleida, and a research assistant, benefiting from a research fellowship [SFRH/BTI/33897/2009] awarded by the Fundação para a Ciência e a Tecnologia within the project (INVENT/ooor/2007).

This article was produced within the research project "The Development of European Waterways, Road and Rail Infrastructures: A Geographical Information System for the History of European Integration (I825-2005)," as part of the EUROCORES program of the European Science Foundation. It was financed by the Fundação para a Ciência e a Tecnologia in Portugal (INVENT/oooI/2007).

(C) 2OI I by the Massachusetts Institute of Technology and The Journal of Interdisciplinary History, Inc.

I António Lopes Vieira, The Role of Britain and France in the Finance of Portuguese Railways, 1850-1890 (Leicester, 1983); Magda Pinheiro, Chemins de fer, structure financière de l'état et dépendance extérieure au Portugal (1850-1890) (Paris, 1986); Maria Fernanda Alegria,

1 LINE SHORT

REGULAR

1 LINE LONG 
This article is centered on the relationship between the railways and demography - the influence of accessibility to railways on the evolution of population, urban centers, and internal migration. It pays particular attention to the way in which trains have influenced the population and urban dynamics of different regions, suggesting that they had a positive impact on population growth, urban development, and internal migration. Their effect, however, was not the same in all parts of the country; in reality, railways seem to have reinforced pre-existing regional inequalities.

The period under study, from I80 I to I930, includes the years before the arrival of trains in 856 , thus allowing a long-term perspective. Nonetheless, this article pays special attention to the decades that witnessed the construction of the railway network; the analysis ends with the ascendance of modern roads. Indeed, in Portugal, as in the rest of Europe, motorization became a central issue after World War I. Following a movement sponsored by the League of Nations that promoted the road network as an increasingly vital element in the transport system in 1927, the Junta Autónoma das Estradas was created to undertake a major restructuring of the country's roads. Alongside the government's initiative came an increase in passenger-bus services, which clearly competed with the railways during the I93 Os. $^{2}$

The research herein used a set of tools capable of treating considerable amounts of historical data, such as population censuses; in the process, thousands of records were gathered. The relational database created to manage this information was linked to a geographical information system (GIS) representing cartographical data and allowing the development of spatial and quantitative analyses that would otherwise have been difficult to perform.

A organização dos transportes em Portugal (1850-1910): As vias e o tráfego (Lisbon, I990); Álvaro Ferreira da Silva and Lara Tavares, "Transport History in Portugal: A Bibliographical Overview," in Michèle Merger and Marie-Noëlle Polino (eds.), COST 340: Towards a European Intermodal Transport Network: Lessons from History: A Critical Bibliography (Paris, 2004), I26-I36; Maria Eugénia Mata and Tavares, "The Value of Railways for Portuguese Consumers on the Eve of the First World War," Transportes, Servicios y Telecomunicaciones, VII (2004), 8I-Ioo; Mata, "As Bees Attracted to Honey: Transport and Job Mobility in Portugal, I890-I950," Journal of Transport History, XXIX (2008), I73-I92; Angela Salgueiro, A Companhia Real dos Caminhos de Ferro Portugueses, 1859-1891 (Lisbon, 2008); Pinheiro, Cidade e caminhos de ferro (Lisbon, 2008).

1 LINE SHORT

REGULAR

1 LINE LONG
2 Frank Schipper, Driving Europe: Building Europe on Roads in the Twentieth Century (Amsterdam, 2008), I2I-I57; Lopes Vieira, "Os transportes rodoviários em Portugal, I900-I940,"

Revista de História Económica e Social, V (1980), 84-9I. 
PORTUGAL, I8OI-I930 | 3I

CONCEPTS, METHODOLOGIES, AND SOURCES

Maps and Data Interpolation Portugal's smallest territorial unit is the parish. In I9I I, the year that serves as a reference for data interpolation in this article, the vast majority of them (68 percent) were smaller than $20 \mathrm{~km}^{2}$ in area, although there were important regional differences. The parishes were also the most stable territorial units, totaling 4 , IOO in I8OI, 3,640 in I9I I, and 4,005 in I99I.

No systematic records of the changes to parish boundaries exist almost to this day. To retrace the history of these units means relying on the lists of parishes published during the great territorial reforms of the first half of the nineteenth century and on those of the population censuses. Other sources include cartography, gazetteers, and local histories. Analysis of the available data indicates that the change in the number of these territorial divisions over time resulted mainly from the merging of two or more parishes or from the splitting of a parish into two or more units. Given the lack of systematic information, it is almost impossible to map detailed changes of their boundaries, especially in the nineteenth century. Thus, the maps produced in this article covering the period from I8OI to 200 I represent those mergers or divisions without any of the micro-changes that might have occurred, except in the most important cases, among them in the city of Lisbon. The mapping process employed a retrospective methodology, starting from current maps to draw the older ones. ${ }^{3}$

The declining number of parishes before I9 I and the subsequent increase, with obvious implications for the average area per parish, poses certain difficulties when comparing data from various censuses. It risks the infiltration of errors and bias into the analysis. This situation is no different from that in other countries. Various methods have been proposed to overcome these problems, rang-

3 The maps used in this article have been developed by several teams since the early I99os. Initial results were presented at the Ninth International Conference of the Association for History and Computing in I994, giving rise afterward to several printed publications-among them, Silveira, Margarida Lopes, and Cristina Joanaz de Melo, "Mapping Portuguese Historical Boundaries with a GIS," in Onno Boonstra, Geurt Collenteur, and Bart van Elderen (eds.), Structures and Contingencies in Computerized Historical Research (Hilversum, 1995), 245252; Silveira, Território e Poder: Nas Origens do Estado Contemporâneo em Portugal (Cascais, 1997). The results have also been available on the Internet since 200I (www.fcsh.unl.pt/atlas) and more recently on a website based on open source software (http://www.fcsh.unl.pt/ memorias).

1 LINE SHORT

REGULAR

1 LINE LONG 
32 Silveira, Alves, lima, AlcÂntara, ANd Puig

Table 1 Population Affected by the Interpolation Process (\%)

\begin{tabular}{lcccccc}
\hline CASES & I 864 & I 878 & I 890 & I900 & I920 & I930 \\
\hline I & 92.0 & 9 I.5 & 96.5 & 97.3 & 97.2 & 92.7 \\
2 & $2 . \mathrm{I}$ & 2.3 & I.8 & I.6 & I.I & 4.4 \\
3 & I.5 & I.5 & I.7 & I.I & O.I & O.I \\
4 & 4.4 & 4.7 & O & O & I.6 & 2.8 \\
Total & IOO & I0O & I0O & IOO & IOO & IOO \\
\hline
\end{tabular}

ing from the areal-weighting interpolation technique to more complex models. ${ }^{4}$

The procedure adopted for this article attempted to minimize errors by identifying the year that required the smallest number of splits in the interpolation process, thus affecting the lowest percentage of the total population. The yearigi I qualified since it had the smallest number of parishes, and it occupies a central point in the period under consideration. As can be seen in Table I, the overwhelming majority of people in the various censuses were not affected by the interpolation process; the parishes where they were registered suffered no boundary changes between the source and the target years (case I). However, three other cases were possible - the merging of two or more parishes between the source year and the target year (case 2); the division of a parish in the source year into two or more parishes in the target year (case 3); and the particular case of Lisbon's urban parishes, which had their limits profoundly re-organized in I 885 (case 4). Case 2 required only the aggregation of data in the target year, whereas cases 3 and 4 required the interpolation procedures described below.

With regard to Lisbon, we decided to use the interpolation method by weighting areas, recognizing that this procedure could generate errors, partly due to differences in population density between the interpolated areas, especially when they were both rural and urban. However, in the case under consideration, the parishes

1 LINE SHORT

REGULAR

1 LINE LONG
4 Ian Gregory and Paul Ell, "Breaking the Boundaries: Geographical Approaches to Integrating 200 Years of the Census," Journal of the Royal Statistical Society Series A, CLXVIII (2005), 422-426; idem, "Error-Sensitive Historical GIS: Identifying Areal Interpolation Errors in Time-Series Data," International Journal of Geographical Information Science, XX (2006), I36I 38 . 
PORTUGAL, I8OI-I930 | 33

all formed part of the urban center, having approximately the same population density and thus minimizing the errors introduced by this technique. Given that the division of parishes in Portugal seldom involved the level of fragmentation detected in other countries (like Britain), case 3 had no need for complex methodologies. The simple procedure proceeded in four steps: (I) selecting the parishes, in the target year, that corresponded to the division of the parish in the source year; (2) calculating the total population of the target year for all the parishes selected in (I); (3) dividing the population of each parish in the target year by the total calculated in (2); (4) multiplying each of the coefficients obtained in (3) by the total population of the source parish to calculate the proportion of population to be allocated to each parish in the target year. ${ }^{5}$

The methodology described so far allows the representation of data from the censuses carried out between I 864 and I930, using the parish map of I9I I. Even though this methodology carries a risk of error, the percentage of the population affected by these operations never reached more than 6 percent of the total (cases 3 and 4 ) and remained below 3 percent in most years, ensuring a data set and a geographically uniform basis for comparisons over time with a relatively high level of reliability (Table I).

Regions In a classic work published in 1945, Ribeiro argued that Portugal could be divided into three regions-Atlantic North, Inland North, and South. These regions were distinguishable by such characteristics as terrain, climate, settlement, patterns of landholding, and social structure. In Ribeiro's view, the individuality of these areas also had deep historical roots. The Atlantic North included the lowlands of the coast, with a mild climate, dispersed settlement, and rich agriculture, where small and medium-sized rural properties were dominant and urban life was traditionally important. The Inland North corresponded to the highlands, with a continental climate and poor agriculture, a sparse population, and a small number of urban centers. The South featured large plains and a Mediterranean climate, where landscape was deci-

5 Silveira, Território e Poder, I37-I40; Gregory and Humphrey Southall, "Putting the Past in Its Place: The Great Britain Historical GIS," in Steve Carver (ed.), Innovations in GIS 5 (London, I998), 2I0-22 I; Alves, "Using a GIS to Reconstruct the Nineteenth Century Lisbon Parishes," in Humanities, Computers and Cultural Heritage: Proceedings of the XVIth international conference of the Association for History and Computing (Amsterdam, 2005), I2-I7.

1 LINE SHORT

REGULAR

1 LINE LONG 


\section{Silveira, Alves, lima, AlCÂNTARA, AND PUig}

sively marked by the latifundia, generating a particular social structure. The population lived mainly in villages, and urban centers had a certain degree of importance. Ribeiro's regional division influenced many historians, including Mattoso, who studied the origins of Portugal using this conceptual framework. Taking a different perspective, Justino, in his analysis of the development of the domestic market, noted the contrast between two regions - the North, clustered around Oporto, and the South, centered on Lisbon. ${ }^{6}$

The territorial division based on three areas seems appropriate for a study on the effect of accessibility to railways, since it separates the mountainous region of the North, which has historically suffered from difficult communications. It also helps to consider trends in Portugal within the broader context of the Iberian Peninsula as a whole, as will be evident in due course. But in the GIS employed in this study, Ribeiro's boundaries were modified principally to take the geographical relief into better account, given its influence on accessibility. Hence, the Atlantic North region was defined as the coastal area north of the river Tagus below $300 \mathrm{~m}$ altitude. This area is separated from the Inland North by the mountains parallel to the coast. The mountains also define the boundary between this region and the Mediterranean South, where the overwhelming majority of the land is again below $300 \mathrm{~m}$ altitude (see Figure I).

Urban Population The definition of urban center is a popular topic within Portuguese and international historiography. Along with the various criteria that scholars have proposed, those evinced by the primary sources must also be taken into account. The definition of urban center herein is an agglomeration with a de facto population of 5,000 or more inhabitants in its total number of parishes. The parish can stand as the fundamental unit because it is the most detailed one that is common to every Portuguese census and the only one that can support a comparative historical, urban spatial analysis. The adoption of the minimum limit of 5,000 inhabitants was borne of the need to take into account the small size of Portu-

1 LINE SHORT

REGULAR

1 LINE LONG
6 Orlando Ribeiro, Portugal, o Mediterrâneo e o Atlântico: estudo geográfico (Coimbra, I945); idem, "Cidade," in Joel Serrão (ed.), Dicionário de História de Portugal (Oporto, I975), II, 60-66; José Mattoso, Identificação de um país: ensaio sobre as origens de Portugal 1096-1325 (Lisbon, I985); David Justino, A formação do espaço económico nacional (Lisbon, I989), II, I36-I37. 
PORTUGAL, I8OI-I93O | 35

Fig. 1 Portugal's Three Regions

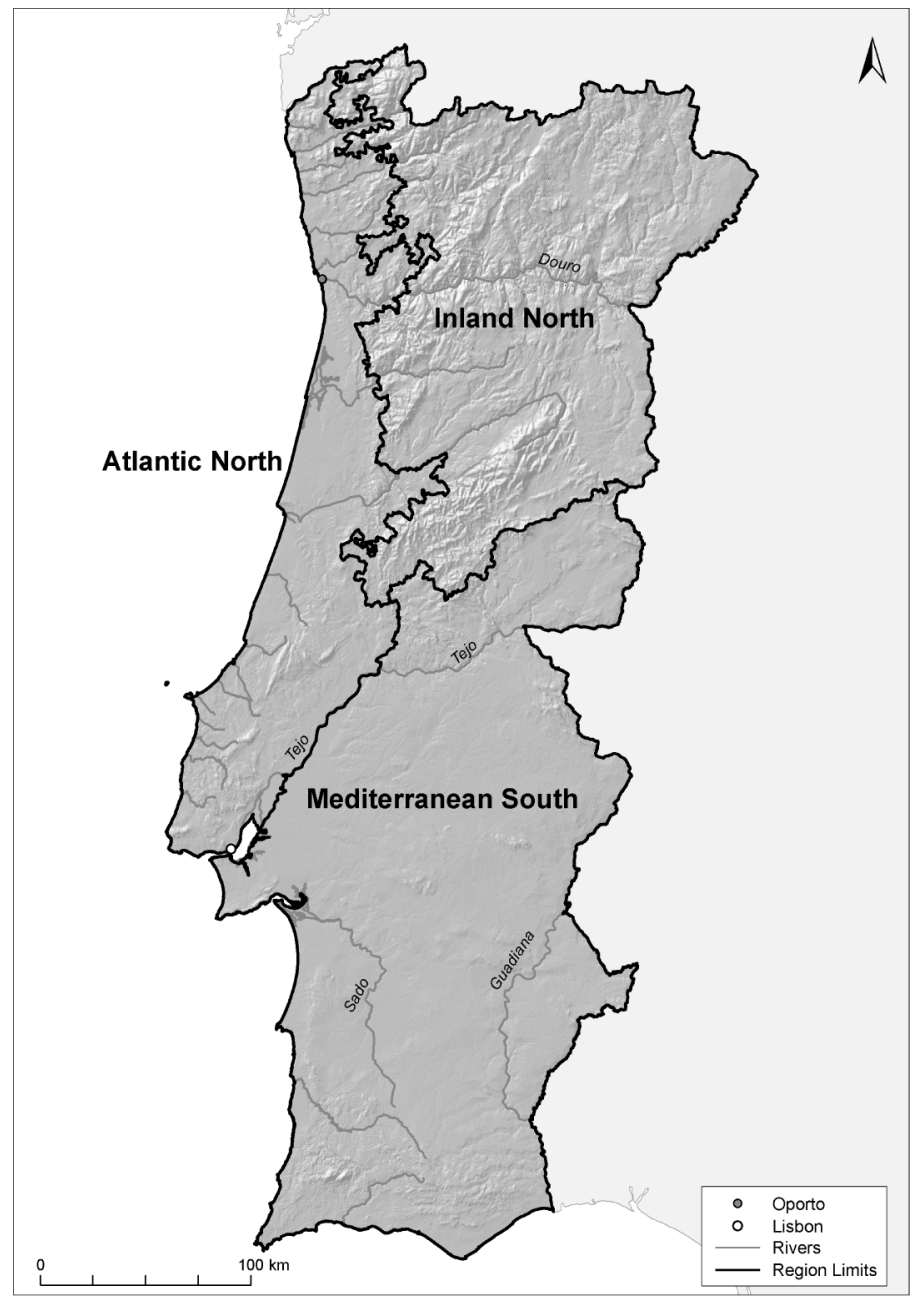

guese urban centers throughout the period covered by the database. $^{7}$

To select the urban agglomerations existing throughout the different years and to avoid the inclusion of parishes with large but scattered populations that were not part of any urban center, the censuses from I9I I and I940 were used as ancillary data. In fact,

7 The figure of 5,000 inhabitants was adopted as a quantitative criterion for selection of the urban population starting with the 1890 census. Hitherto, cities-including district capitals, 
these censuses identify not only the total population of each parish but also the people living in each of its settled areas. The I9I I census helped to identify urban centers in I864, I878, I890, and I900, and the I940 census disclosed the centers in I920 and I930.

Accessibility Since parishes are the smallest territorial units on a map that can provide population data, they would seem to be a good place to start when exploring railway accessibility. In the original outline for this study, a parish had access to a railway only when it had a station. This criterion proved to be too restrictive, especially in flat-land areas, since it tended to exclude neighboring parishes with a station not far away. Therefore, the understanding of accessibility was broadened to include parishes with a centroid no more than $5 \mathrm{~km}$ away from a station. The application of these two conditions turned out to be well suited to the characteristics of the different regions. The criteria chosen apply equally to areas where the parishes are small and to others where they are larger, as well as to flat-land and mountainous regions

Migrant Population The censuses do not contain data about migrant populations. However, since I890, they indicate, for each parish, the number of people born outside the municipality where they were at the time of the survey. Unfortunately, the sources disclose neither where these people lived nor their place of birth, information that is crucial to the study of migration movements. In any case, the data supplied are suggestive, although they must be treated with great caution. They provide, above all, an idea of how attractive various places were for migrants.

The Source and Quality of the Population Data The population data in this article come from nine different censuses. The oldest one, in I $80 \mathrm{I}$, was performed by the church hierarchy, acting independently, although in response to a governmental requirement, and it was based on the parish registers; the same registers were also the source of the I 849 census, but, on this occasion, priests acted under the authority of state officials. who supervised the entire process. In the history of population censuses in Portugal, I 864 repre-

\begin{tabular}{l}
1 LINE SHORT \\
\hline REGULAR \\
1 LINE LONG
\end{tabular}

diocesan sees, and judicial seats-were simply classified by qualitative criteria, of a juridical nature. 
sents the beginning of the modern era, since the census of that year, was executed at a given date by public authorities, who collected the information using the same questionnaire all over the country. Despite its ecclesiastical origins, the I8O I census is considered a reliable source. ${ }^{8}$

The CONStruction of the Railways Until i 822, Portugal was the head of a vast colonial empire centered on Brazil. Brazil's independence caused Portugal severe economic difficulties for decades especially in its Atlantic North region, where most of the commercial and industrial activities were concentrated. Portugal began to recover in the second half of the nineteenth century, but agriculture continued to be a dominant activity despite the relative dynamism of the industrial sector, the growth rate of which was not fast enough to keep up with that of more advanced countries. ${ }^{9}$

The construction of the railways was part of an attempt to modernize the country. Portugal's first railway track, which ran between Lisbon and Carregado in I 856 , was $36 \mathrm{~km}$ long. By that time, England had more than Io,00o km of track; France had almost $6,000 \mathrm{~km}$; and even Spain had about $500 \mathrm{~km} .{ }^{10}$

The reason for Portugal's late start is rooted in its political instability, its economic difficulties, and its strategic uncertainty regarding the nature of the railway sector. One of the key issues was whether the government would construct and operate the railway itself or merely give a boost to private enterprise. There were also doubts regarding the form of financial support to be provided by the state. Moreover, the plan for the network was long in the making; when it was completed in I 877, Portugal already had approximately $\mathrm{I}, 000 \mathrm{~km}$ of railways. ${ }^{11}$

The prevailing practice was a mixture of private enterprise

8 Silveira (ed.), Os Recenseamentos da População Portuguesa de 1801 e 1849, Edição Crítica (Lisbon, 200I).

9 Justino, A formação do espaço económico nacional; Jaime Reis, "The Historical Roots of the Modern Portuguese Economy: The First Century of Growth, I850s to I950s," in Richard Herr (ed.), The New Portugal: Democracy and Europe (Berkeley, I993), I26-I 48; Reis, O atraso económico português (1850-1930) (Lisbon, I993); Pedro Lains, "Growth in a Protected Environment: Portugal, I850-I950," Research in Economic History, XXIV (2007), I2I-I63.

Io Alegria, A Organização dos Transportes, 2I 4; RENFE (Red Nacional de los Ferrocarriles Españoles), Los ferrocarriles y el desarrollo económico de Europa occidental durante el siglo XIX (Madrid, I98I)

I I Alegria, A organização dos transportes; Pinheiro, "Le rôle de l'Etat dans la construction des chemins de fer du Portugal au XIXe siècle," Histoire, Économie et Société, XI (I992), I73-I84.

1 LINE SHORT

REGULAR

1 LINE LONG 
38 Silveira, Alves, lima, AlCÂNTARA, AND PUiG

Fig. 2 Evolution of the Railway Network

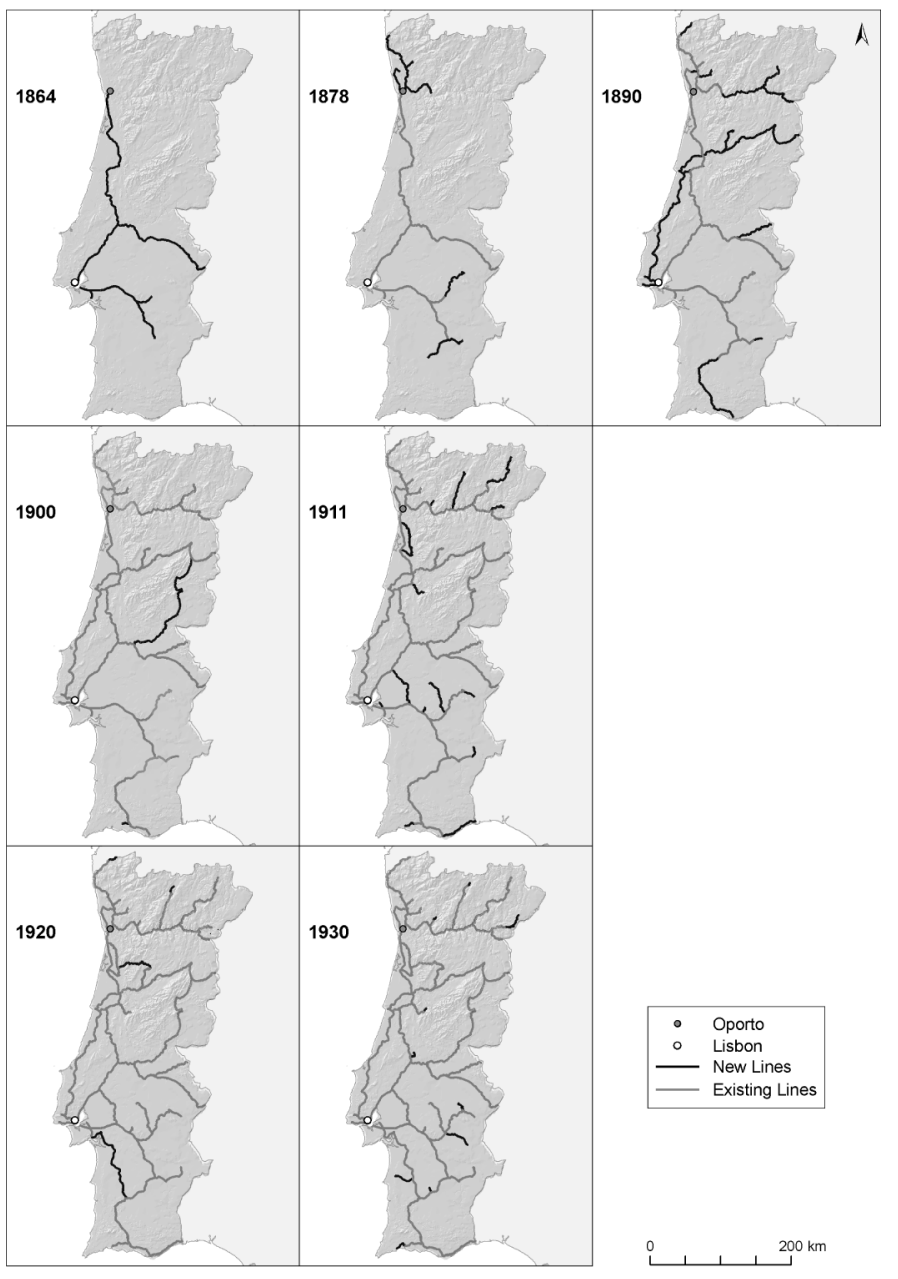

and state intervention, the latter often determined by the lack of interest from private investors or from difficulties in raising capital in times of economic crisis. The priorities are clearly visible in the lines that were operating in I864, connecting Lisbon to Oporto, Lisbon to Spain, and Lisbon to the South (see Figure 2). The pivotal role of the capital and connections to Spain (and thus to the rest of Europe) and Oporto were the priorities for railway conREGULAR struction in these early years. Eventually, Oporto was to make fur- 
PORTUGAL, I8OI-I930 | 39

ther connections and the network to extend into areas hitherto without access to trains. ${ }^{12}$

The realization of these goals was not immediate, however. The late I860s and the first half of the I 870 s saw new political upheavals and economic hardships. Until i 878 , the only new development was the growth of the network toward the extreme northwest (the Minho line), thus covering the entire region of the Atlantic North. The great period of construction, which occurred between I 878 and I 890 , marked the arrival of the railway to the Inland North, to the extreme South, and to the coastal area north of Lisbon (a major supplier for the capital), as well as the opening of four international connections.

The network, which had grown to $3,423 \mathrm{~km}$ during the I930s, was to be completed with the opening of regional lines, some of which are of considerable significance: The Beira Baixa line opened from I89 I to I 893, linking the Mediterranean South to the Inland North; the branch to the northeast became operational from the early twentieth century; the branch connecting the network south of the Tagus to the north of that river was concluded in 1904; and by I906, trains reached the extreme southeast coast of the Mediterranean South.

POPULATION The censuses of I8OI and I849 show, not surprisingly, that the Portuguese population grew slowly (0.36 percent per year). From I 849 to I9I I, the compound annual growth rate (CAGR) more than doubled (0.79 percent), as economic performance improved and efforts to modernize the country produced some results. Between I9I I and I920, the population almost stagnated, mainly because of high rates of emigration, the effects of World War I, and the influenza epidemic of I9I8; thereafter, its growth resumed, values reaching more than I percent per year. This population-growth pattern is a result of a late demographic transition and is similar to that of other southern European countries (see Figure 3$)^{13}$

I2 Antonio Gómez Mendoza, "La modernisation des transports dans la Péninsule Ibérique au XIXe siècle," Histoire, Économie et Société, XI (I992), I45-I 56; Juanjo Olaizola Elorid, "Los orígenes de las comunicaciones ferroviarias hispano-portuguesas," Revista de Historia Ferroviaria, IX (2008), 5-64.

I 3 In the first half of the nineteenth century, Portugal's CAGR was lower than Italy's (o.6\%) or Spain's (0.6\%), but thereafter, until the end of the century, Portugal's growth was similar to Italy's and Spain's, though still far from that of other states in northern Europe, such as Bel-

1 LINE SHORT

REGULAR

1 LINE LONG 
Fig. 3 Evolution of the Population by Region

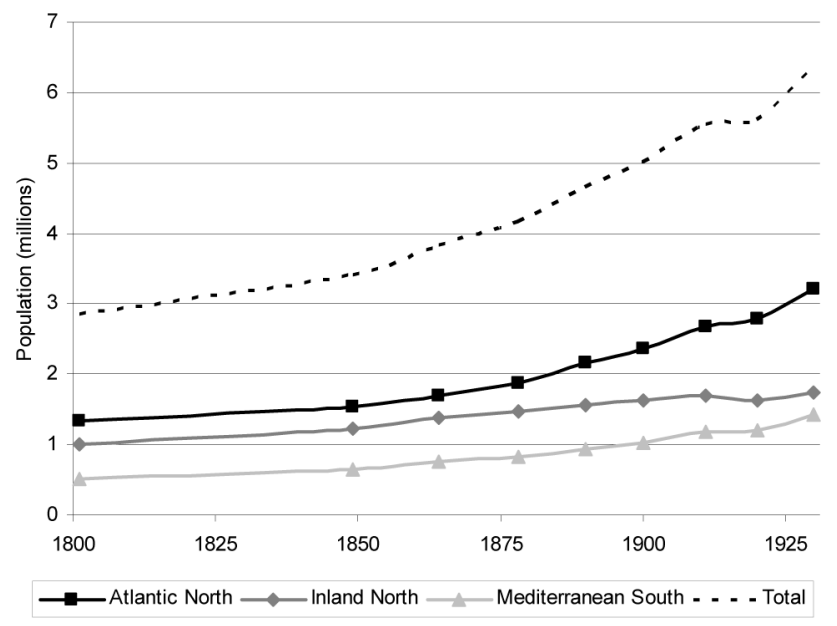

As shown in Figure 3, until I864, the three Portuguese regions had a parallel development, but from that point forward, the Inland North was unable to follow the expansion of population in the Atlantic North and in the South. As a result, in I930, the populations of the South and the Inland North were about equal.

That the percentage of the total Portuguese population living in the Inland North, clearly visible in Figure 4, steadily declined is significant. However, this trend is not unique; a similar trend was underway in the hinterland of the rest of the Iberian Peninsula. Another key feature apparent in Figure 4 is the large share of the population (46 percent) concentrated in the Atlantic North in the early nineteenth century. After a slight decrease by I 864 , this area continued to gain momentum, surpassing 50 percent of the total population in I930. The South also had a positive long-term evolution. ${ }^{14}$

gium (I.2\%), the Netherlands (I.5\%), and Britain (1.6\%). Neil Tranter, Population since the Industrial Revolution: The Case of England and Wales (London, I973), 43; Massimo Livi Bacci, The Population of Europe: A History (New York, 2000), I32; David Reher, "The Demographic Transition Revisited as a Global Process," Population, Space and Place, X (2004), 22, 35, 37; Teresa Rodrigues Veiga, A população portuguesa no século XIX (Oporto, 2004), 20-22; idem, "A transição demográfica," in Pedro Lains and Ferreira da Silva (eds.), História Económica de Portugal (Lisbon, 2005), III, 37-63.

1 LINE SHORT

REGULAR

1 LINE LONG
I4 The tendency to reinforce the coastal region to the detriment of the interior is best understood in the context of the Iberian Peninsula as a whole. At the time, Spain was undergo- 
PORTUGAL, I8OI-I93O | 4I

Fig. 4 Population Distribution by Region (\%)

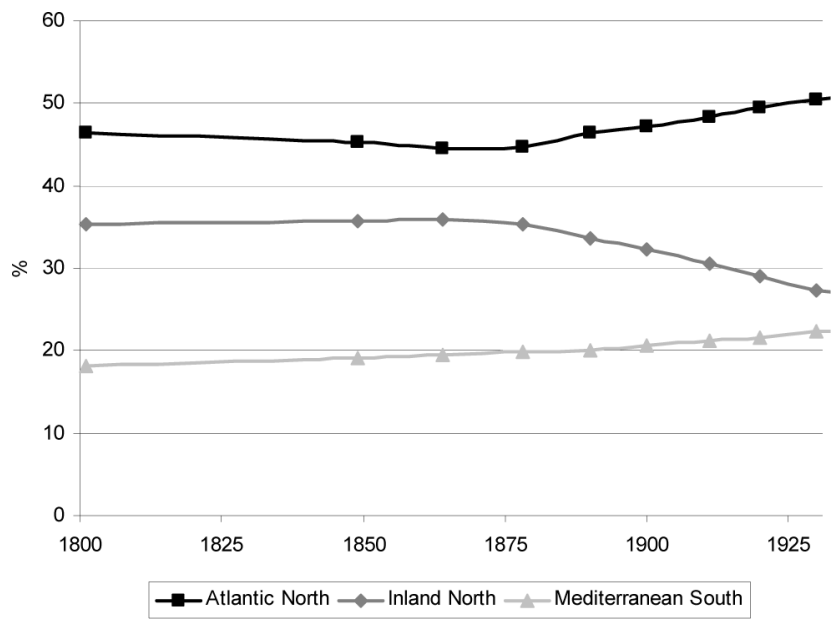

The development described above is reflected in the variation of population density in the different regions, as shown in Figure 5 (maps published for the first time). In I 80 I, the population density of the Atlantic North contrasted with that of both the Inland North and the South, where rates were exceedingly low. Ninety years later, the increase in density of the Atlantic North and of the South is clearly visible, especially in the coastal area of the extreme south (Algarve). Both regions reinforced this growth trend in I930, unlike the Inland North, where the situation seems not to have changed significantly.

URBANIZATION The rate of European urbanization (excluding Russia) changed drastically from I9 percent in I 850 to 48 percent in I930. In the case of Portugal, following the criteria adopted herein, the increase in the rate of urbanization was more modest, registering lower values - around I 3 percent in I 864 and 24 percent in I930, which was half of the value reported by Bairoch for

ing a similar process, which had already begun in the mid-nineteenth century. Juan Pons Izquierdo, Dolores López, and Carolina Montoro Gurich, "Del interior a la costa: dinámica espacial de la población española a lo largo del siglo XX," in VII Congresso de la Asociación de Demografía Histórica (Granada, 2004), 8. Similar tendencies are evident in France and Ireland. Jordi Martí-Henneberg, "Empirical Evidence of Regional Population Concentration in Europe, I870-2000," Population, Space and Place, XI (2005), 272-273.

1 LINE SHORT

REGULAR

1 LINE LONG 
42 Silveira, Alves, lima, alcântara, AND puig

Fig. 5 Population Density

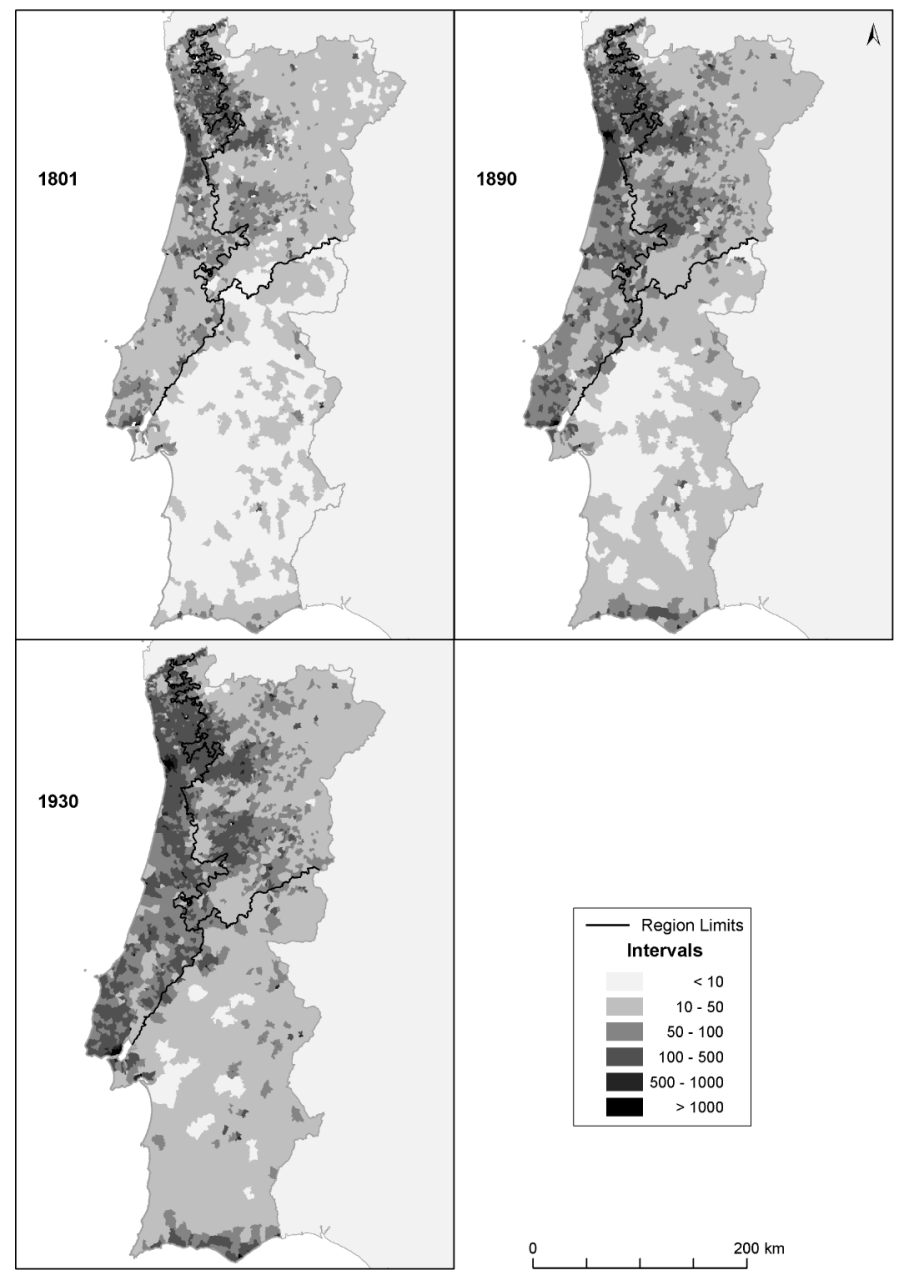

the whole of Europe in I930. These rates are a clear sign of the overall limitations of the country's economic and social modernization. ${ }^{15}$

Urbanization in Portugal was generally slow and gradual; the two periods of greater acceleration were insufficient to compensate for its structural weakness. The first of these moments resulted

\begin{tabular}{l}
$\frac{1 \text { LINE SHORT }}{\text { REGULAR }}$ \\
\hline 1 LINE LONG \\
\hline
\end{tabular}

I5 Paul Bairoch, Cities and Economic Development: From the Dawn of History to the Present (Chicago, I988), 216. By comparison with Spain, this limitation in urban growth was sig- 
PORTUGAL, I8OI-I930 | 43

Table 2 Evolution of Urban Population

\begin{tabular}{|c|c|c|c|}
\hline \multirow[b]{2}{*}{ CENSUSES } & \multirow{2}{*}{$\frac{\text { PORTUGAL }}{\text { POPULATION }}$} & \multicolumn{2}{|c|}{ URBAN CENTERS } \\
\hline & & POPULATION & $\%$ \\
\hline I 864 & $3,828,356$ & 502,890 & I $3 . I 4$ \\
\hline I 878 & 4, I 59,9 I 5 & 584,927 & I 4.06 \\
\hline I 890 & $4,660,422$ & 767,3 I 4 & I6.46 \\
\hline 1900 & $5,015,268$ & 895,733 & I 7.86 \\
\hline I9I I & $5,547,567$ & $\mathrm{I}, 05 \mathrm{I}, \mathrm{I} 87$ & I 8.95 \\
\hline 1920 & $5,622,457$ & I,250,696 & 22.24 \\
\hline 1930 & $6,360,347$ & I, 5 I 5,089 & 23.82 \\
\hline
\end{tabular}

from the territorial expansion of the concelho (municipality) of Lisbon during the mid-I 880 os, when its area increased roughly sevenfold. This alteration led to an increase in the proportion of the total urban population in the capital from 36.9 percent to 39. I percent. The second moment was a rise of more than 3 percent between I9I I and I920 due to the appearance of seventeen new urban centers. Curiously, this apparent vitality in Portuguese urbanization occurred at precisely the time when the rate of population growth was slowing down (see Table 2). ${ }^{16}$

The low level of urbanization in Portugal is also illustrated by its number of small centers (less than I0,000 inhabitants). These centers continually declined in their share of the population, however; in I900, they had 20.4 percent of the total, whereas the medium-sized areas (between 10,000 and 40,000 inhabitants) had risen to 2I.I percent. Lisbon and Oporto, situated in the Atlantic North region, had a huge preponderance of people, together between 54 percent and 60 percent of the country's total (during this period, the population of Lisbon was more than double that of

nificant. In I 860, $22.5 \%$ of Spain's population resided in urban agglomerations of more than 5 ,000 inhabitants; by I930, the figure raised to $37 \%$. David Reher, "Ciudades, procesos de urbanización y sistemas urbanos en la Península Ibérica, I550-I99I," in Manuel Guardia, Francisco Monclús, and José Luis Oyón (eds.), Atlas Histórico de Ciudades Europeas (Barcelona, 1994), I, 25. See also Gabriel Tortella, El Desarrollo de la Espana Contempordnea: Historia Economica de los Siglos XIX y XX (Madrid, 2006), 37.

I6 Ana Bela Nunes, A rede urbana portuguesa e o moderno crescimento económico (Lisbon, I989); Pedro Telhado Pereira and Mata, Urban Dominance and Labour Market Differentiation of a European Capital City: Lisbon 1890-1990 (London, I996); Ferreira da Silva, "A evolução da rede urbana portuguesa (I80I-I940)," Análise Social, XXXII (I997), 779-8I 4; Nuno Pires Soares, O sistema urbano português, 1890-1991 (Lisbon, I998).

1 LINE SHORT

REGULAR

1 LINE LONG 
44 Silveira, Alves, lima, AlCÂntara, AND puig

Table 3 Urban Population by Region (\%)

\begin{tabular}{lrrrrrrr}
\hline REGION & I864 & I878 & I890 & I900 & I9I I & I920 & I930 \\
\hline North Atlantic & 2I.I6 & 22. I I & 25.89 & 27.79 & 29.53 & 33.07 & 34.89 \\
Mediterranean South & I5.26 & I5.70 & I6.49 & I 8.I7 & I7.7 I & 22.65 & 23.56 \\
Inland North & 2.07 & 2.86 & 3.42 & 3.19 & 3.07 & 3.50 & 3.64 \\
Total & I3.I4 & I4.06 & I6.46 & I7.86 & I 8.95 & 22.24 & 23.82 \\
\hline
\end{tabular}

Oporto, the second largest city). This rise of medium-sized centers is notable both in the Atlantic North and in the Mediterranean South; in this latter region, it had its greatest surge at the turn of the twentieth century.

Throughout the period under study, the Atlantic North, which was already the most urbanized region, enjoyed a higher rate of urbanization than any other region, by far. The rate in the South was also high and rising but not so that of the Inland North, which is noteworthy for its urban lethargy throughout the period (see Table 3). Not only did it have few urban centers (seven); almost all of them were small (less than Io,ooo inhabitants). The exception was the city of Covilhã, which joined the medium-sized ranks in $\mathrm{I} 878$.

POPULATION AND RAILWAYS Not until i9i I, fifty-five years after the opening of the first railway line, did coverage reach half of the population ( 5 I percent). In I930, it had risen to only 56 percent. Given the construction policy and the population distribution already analyzed, it is hardly surprising that the Atlantic North always had the highest percentage of people being served by the railway, in contrast to the Inland North, where railway penetration was always the weakest. Periods of significant increase in accessibility can be identified for each region (see Table 4 ). In the Atlantic North, the rise occurred between the I860s and I870s, and in the South, only during the early years of the twentieth century. In the Inland North, the spread of railways was gradual after I 890; even at the end of the period under study, trains never directly served more than one-third of the population.

The effect of railway accessibility on the population growth

1 LINE SHORT

REGULAR

1 LINE LONG of the country as a whole is reflected in the fact that parishes with

access grew faster than those without it. Moreover, the difference
1226 - JIH4201 p. 44

Journal of Interdisciplinary History 
PORTUGAL, I8OI-I930 | 45

Table 4 Spread of Railways into the Population by Region (\%)

\begin{tabular}{|c|c|c|c|c|c|c|c|c|}
\hline REGION & RAILWAY & I 864 & I 878 & I 890 & I900 & I9I I & I920 & I930 \\
\hline \multirow[t]{3}{*}{ North Atlantic } & Without & 70.8 & 53.7 & 38.1 & 36.9 & 31.0 & 30.0 & 28.0 \\
\hline & With & 29.2 & 46.3 & 6I.9 & $63 . \mathrm{I}$ & 69.0 & 70.0 & 72.0 \\
\hline & Total & IOO & IOO & IOO & IOO & IOO & IOO & IOO \\
\hline \multirow[t]{3}{*}{ Mediterranean South } & Without & 88.3 & $85 \cdot 3$ & 77.5 & 7I.3 & 57.2 & 55.4 & $5 \mathrm{I} .7$ \\
\hline & With & I I. 7 & $\mathrm{I} 4.7$ & 22.5 & 28.7 & 42.8 & 44.6 & 48.3 \\
\hline & Total & IOO & IOO & IOO & IOO & IOO & IOO & IOO \\
\hline \multirow[t]{3}{*}{ Inland North } & Without & IOO.O & 98.9 & 80.5 & 77.8 & 72.0 & 69.6 & 67.5 \\
\hline & With & 0.0 & I.I & 19.5 & 22.2 & 28.0 & 30.4 & 32.5 \\
\hline & Total & IOO & IOO & IOO & IOO & IOO & IOO & IOO \\
\hline
\end{tabular}

Fig. 6 Railways and Population Growth (CAGR)

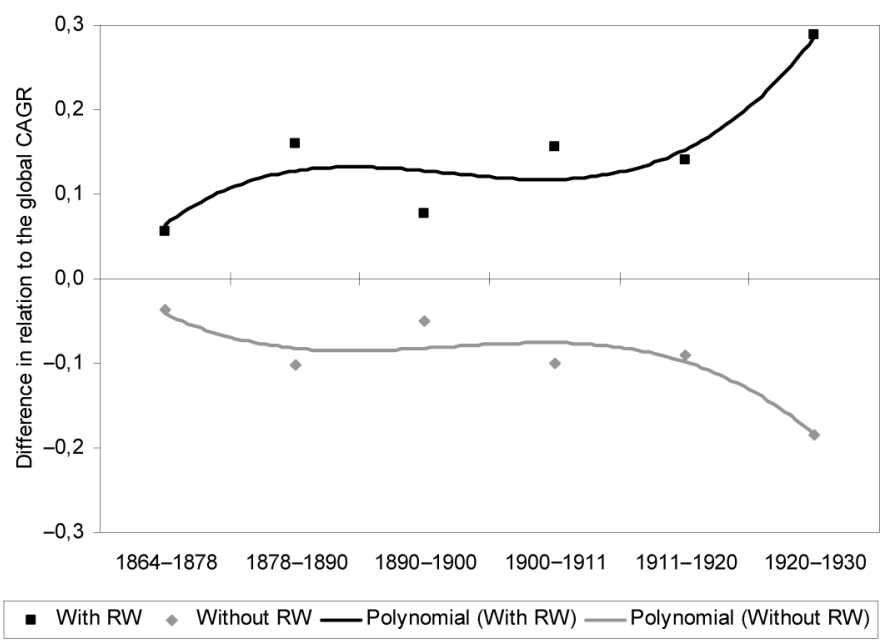

between the two groups increased over time, as can be seen in Figure 6 . The positive impact of the railway is also visible through a comparison of the CAGR of the population immediately before and after access; CAGR was always greater following the arrival of the railway (see Figure 7). The one exception occurred between I 890 and I900, which can be explained by the negative consequences of the Beira Baixa line, the only one built during these years, for the Inland North region (see below).

The observations above are consistent with the Spearman's 1 LINE SHORT REGULAR 1 LINE LONG 
46 Silveira, Alves, lima, AlcÂntara, AND PUig

Fig. 7 Population Growth before and after the Arrival of the Railway

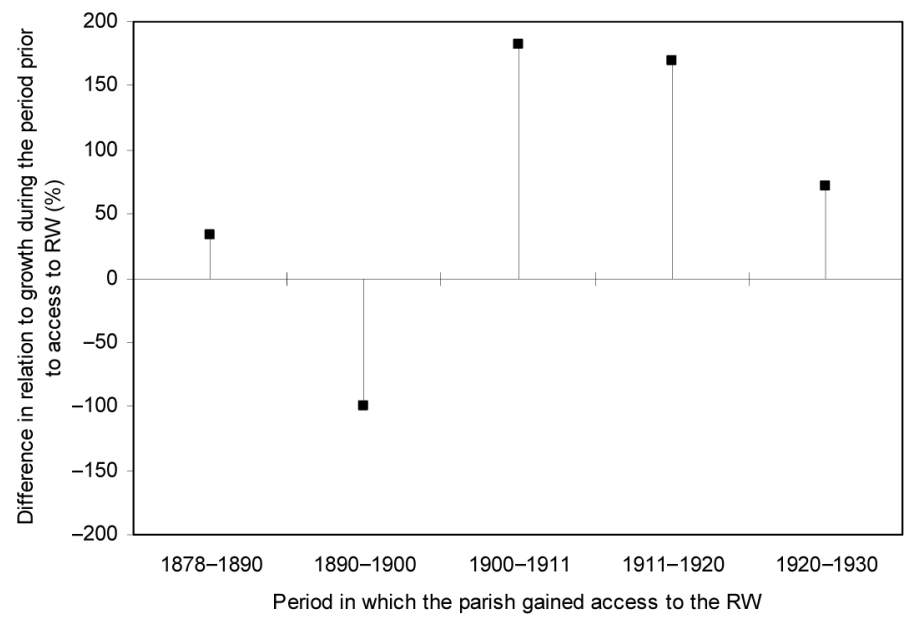

Rank Correlation Coefficient calculated between the period of the arrival of the railway and the CAGR of the population of a given parish from I864 to I930. The value obtained (-0.2I7) is statistically significant; population growth tended to be greater the earlier that the railway became accessible. An equally significant correlation, though less intense (-O.II8), was found for the Atlantic North, though not true for the other regions, reinforcing the idea that the arrival of trains did not have the same impact everywhere, as is suggested by Figure 7 and Table $4 \cdot{ }^{17}$

The routes of the railway network are intimately linked to the geography of the urban centers (see Figure 8). Indeed, the railway sought to connect the thirty centers that already existed while favoring the emergence of twenty new centers in areas that already formed part of the network. Only ten localities that did not have access to trains rose to the category of urban area during the period under study. ${ }^{18}$

I7 The results obtained are similar to those indicated by Gregory and Martí-Henneberg, "The Railways, Urbanisation, and Local Demography in England \& Wales, I825-I9I I," Social Science History, XXXIV (20I0), I99-228. The possibility of applying this methodology to the Portuguese data, making the results comparable with the British case, arose in the context of the aforementioned project, "The Development of European Waterways, Road and Rail Infrastructures."

1 LINE SHORT

REGULAR

1 LINE LONG
I8 Mendoza, "La modernisation des transports," I45-I 56; João Silva, Os Transportes e o Espaço Urbano (Lisbon, I998); Pinheiro, "Portuguese Cities and Railways in the Nineteenth and Twentieth Century," in Ralf Roth and Marie-Noëlle Polino (eds.), The City and the Railway in Europe (Aldershot, 2003), I05-II8; Mata, "As Bees Attracted to Honey," I73-I92.

$$
\begin{gathered}
1226 \text { - JIH4201 p. } 46 \\
\text { Journal of Interdisciplinary History }
\end{gathered}
$$


PORTUGAL, I8OI-I930

47

Fig. 8 Railways and Urban Centers

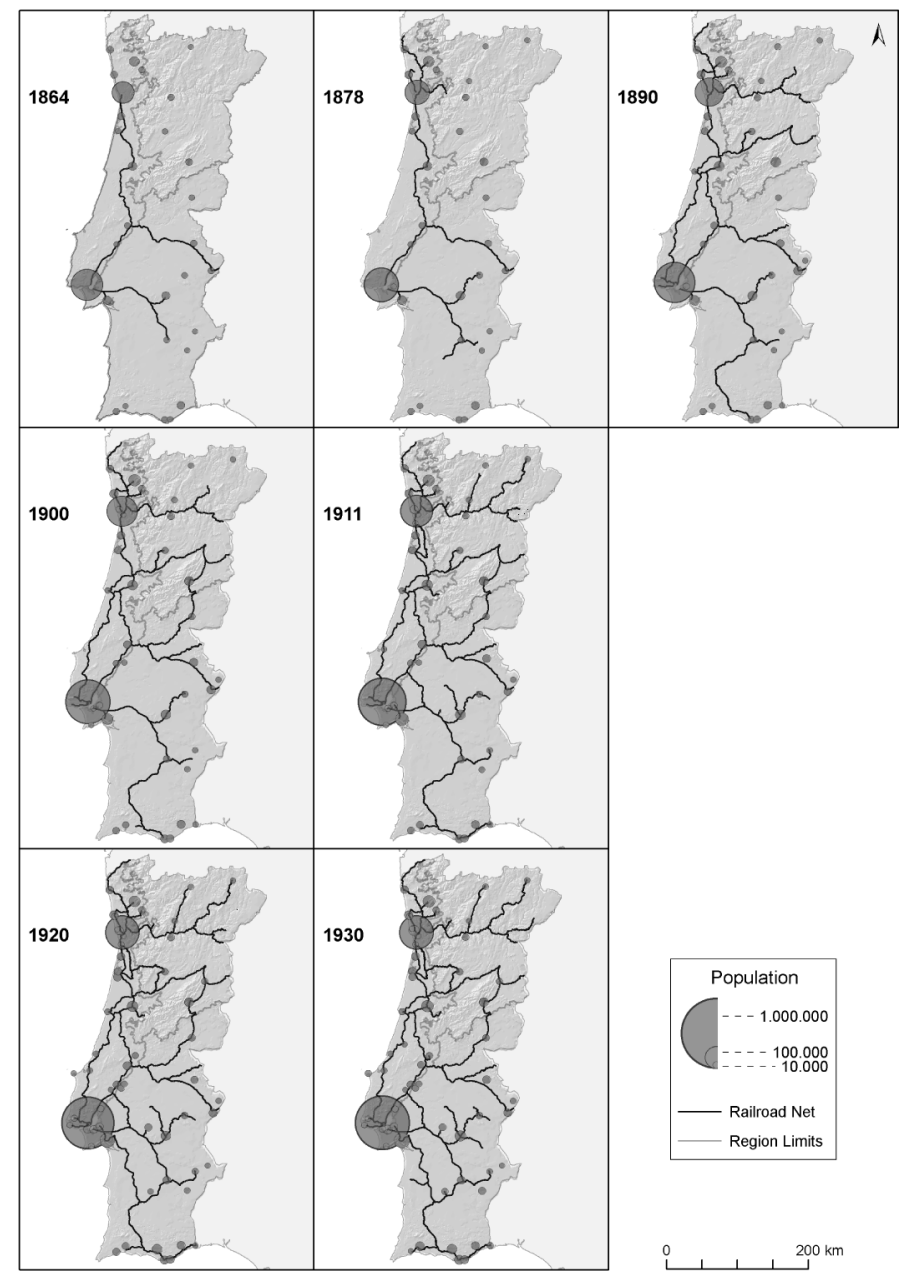

The stimulus of the railway for the appearance of new centers is particularly evident in the Atlantic North. The railway linked ten urban areas that were already in existence in this region, and fifteen more centers emerged as access to the railway network grew. This stimulus is even more noticeable in a comparison of this region with the other two. In the Mediterranean South, more urban centers appeared prior to becoming part of the network (fifteen) than after the creation of a railway connection (four). The railway network reached the Inland North during the I88os. However, no new cities were added to the already weak urban

1 LINE SHORT

REGULAR 1 LINE LONG 
network of this region after the arrival of the railway. The only exception was Guarda, a district capital that did not become an urban center until I920 in spite of being on the Beira Alta line from I 882 and serving as the terminal for the Beira Baixa line from I 892 . Furthermore, the railway did not add to the growth of the urban areas already in existence.

Urban centers without access to railways between I 864 and I9I I grew at a significantly slower pace than those with access. This tendency seems to have reversed in the period that followed, probably because of the conclusion of the main lines in I9I I. The railway's influence on the growth of urban centers seems to have unfolded in two distinct phases - a short-term one, in which the arrival of trains reinforced population growth, and a long-term one, in which the positive effect of the railway's presence declined, apparently no longer a sufficient condition in itself to sustain urban development. ${ }^{19}$

The relationship between the railway and population also involves internal migration. The number of people recorded in each parish who were born outside the concelho to which the parish belonged (an indicator of the migrant population) varied between roughly $5 \mathrm{IO}, 000$ in $\mathrm{I} 890$ and 844,000 in 1930 , the period for which these data are available. This number was always higher than the number of inhabitants in the country's capital, representing, on average, I 3.7 percent of the country's total population, indicating the existence of a relatively important mobility similar to that observed in Spain. ${ }^{20}$

The greater part of this population-on average, 67 percent throughout the period studied-was registered in the Atlantic North; 20 percent was in the South zone; and the rest were in the

1 LINE SHORT

REGULAR

1 LINE LONG

I9 The same hypothesis had already been proposed in a study on urban growth in the United States for the latter part of the nineteenth century by Robert Higgs, "The Growth of Cities in a Midwestern Region, I870-I900," Journal of Regional Science, IX (I969), 369-375. Gregory and Martí-Henneberg seem to be drawing the same conclusion for England and Wales, especially for the large urban centers in "Railways, Urbanisation, and Local Demography."

20 For the period between I 890 and I930, the figures for mobility at the provincial level in Spain, and the district level in Portugal, are close- $9.8 \%$ and $7.8 \%$, respectively. See Javier Silvestre Rodríguez, "Las migraciones interiores durante la modernización económica de España, I860-I930," Cuadernos económicos de ICE, LXX (2005), I64-I66; Ferreira da Silva, "Padrões de mobilidade interna em Portugal na segunda metade do século XIX," in José Vicente Serrão, Pinheiro, and Maria de Fátima Sá e Melo Ferreira (eds.), Desenvolvimernto Económico e Mudança Social (Lisbon, 2009), 375-392.

1226 - JIH4201 p. 48
Journal of Interdisciplinary History


PORTUGAL, I8OI-I930 | 49

Fig. 9 Railways and Migration

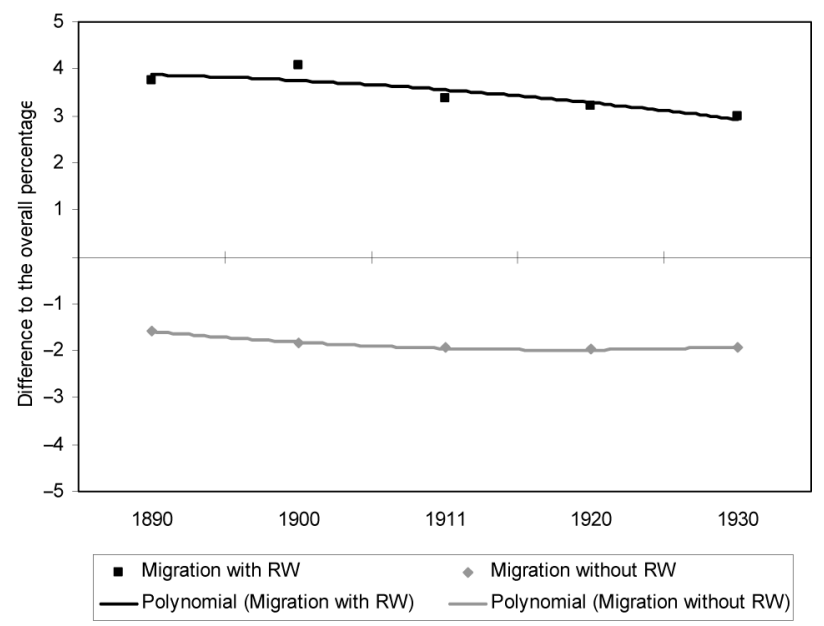

Inland North, the least attractive region from this point of view. A little more than half of the migrant population ( 55 percent) lived in the cities across the country; the urban centers of the Atlantic North region were able to attract the largest share of them $(85$ percent). Studies reveal that Lisbon tended to lose population through migration during the first half of the century, but that this trend had reversed by I 864 . Thus, the data seem to indicate that Portugal was in tune with the rest of Europe, where migration was an important factor in the growth of cities. ${ }^{21}$

The railway may have favored the general population swing described above. Parishes with access to railways usually had a percentage of migrant population that was higher than that of the parishes without access and consistently above the overall mean (see Figure 9). This pattern is evident in both the Atlantic North and the South, but the influence of railway access in the Inland North was significantly less. The differences related to migration between urban areas with and without access are the highest that can be observed, although they tended to decrease with time (see Figure IO).

2 I Rodrigues, Nascer e morrer na Lisboa oitocentista: Migrações, mortalidade e desenvolvimento (Lisbon, I995), I37-I43; Leslie Moch, Moving Europeans: Migration in Western Europe since 1650 (Bloomington, 2003), I26-I3I; Silvestre Rodríguez, "Temporary Internal Migrations in Spain, I860-1930," Social Science History, XXXI (2007), 540.

1 LINE SHORT

REGULAR

1 LINE LONG 
50 Silveira, Alves, Lima, AlCÂntara, AND PUig

Fig. 10 Railways and Urban Migration

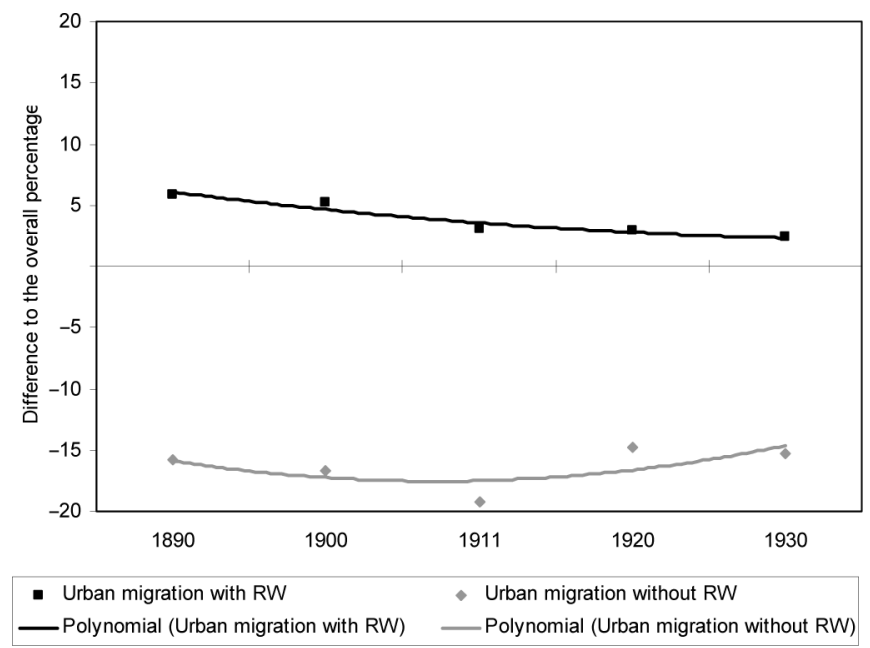

Analysis of the correlation between migration and population growth reveals statistical significance for the parishes with and without access to trains. However, the coefficient calculated through Pearson's method for each decade points to a greater intensity for those with access, especially during the period from I 890 to I9II, for which the corresponding values vary between 0.33 I and 0.242 . In the coastal region, the correlation is generally closer, reaching a value of 0.434 in $\mathrm{I} 890$ (significance $=0.000$; $\mathrm{N}=706$ ) (see Table 5).

The preceding paragraphs confirm the positive contribution of the railways to population growth, reinforcing the data analyzed before, though with different intensities according to the years and regions considered. These differences are further revealed in an analysis of the effect of railway access on the parishes of each region. In the Atlantic North-and the Mediterranean South, after I 890 - the effect is similar to the national pattern. In both cases, parishes with access to trains grew faster than the rest. In the Inland North, however, the population growth rate in the parishes with access fluctuated sharply after the arrival of trains in the I 88 os; it declined until the I920s, only to recover during the following decade. During the period of decline, the growth rate in

1 LINE SHORT

REGULAR

1 LINE LONG these parishes was even slower than that in those without access, thus suggesting that railways might have had a negative impact on 
PORTUGAL, I8OI-I93O | 5I

Table 5 Correlation between Migration and Population Growth

\begin{tabular}{llccc}
\hline & & CORRELATION & SIGNIFICANCE & $\mathrm{N}$ \\
\hline \multirow{2}{*}{ I890 } & With railway & $0.33 \mathrm{I}$ & 0.000 & $\mathrm{I}, \mathrm{O} 8 \mathrm{I}$ \\
& Without railway & $0 . \mathrm{I} 60$ & 0.000 & 2,557 \\
\multirow{2}{*}{ I900 } & With railway & 0.244 & 0.000 & $\mathrm{I}, \mathrm{I} 33$ \\
& Without railway & $0 . \mathrm{I} 26$ & 0.000 & 2,505 \\
\multirow{2}{*}{ I9I I } & With railway & 0.242 & 0.000 & $\mathrm{I}, 333$ \\
& Without railway & 0.209 & 0.000 & 2,305 \\
\multirow{2}{*}{ I920 } & With railway & $0 . \mathrm{I} 49$ & 0.000 & $\mathrm{I}, 384$ \\
& Without railway & $0 . \mathrm{I} 25$ & 0.000 & 2,254 \\
\multirow{2}{*}{ I930 } & With railway & 0.222 & 0.000 & $\mathrm{I}, 424$ \\
& Without railway & $0 . \mathrm{I} 78$ & 0.000 & $2,2 \mathrm{I} 4$ \\
\hline
\end{tabular}

the population growth rate observed in this region. Covilhã is an example of a place where the availability of the railway did not stimulate urban development.

Indeed, railway accessibility, population and urban growth do not always go hand in hand. Covilhã, although located in a relatively isolated region, was an important center for the woolen industry. Contrary to tendencies observed across the country, the demographical boom cycle there (from I864 to I890) was followed by a dramatic break, from a CAGR of 4 percent to one of I.2 percent, which occurred simultaneously with the arrival of the railway (I89I). Prior to the census of I 890, the highest growth rates were observed in urban parishes and in rural ones that were to have access to a railway station in the following decade. By contrast, after I890, the growth trend of the urban areas was reversed; at the same time, the rural parishes served by trains began to grow more slowly than those without access to a railway station.

The second half of the nineteenth century was a period of rapid economic growth in Europe. Following the loss of Brazil, its principal colony, Portugal sought to establish the bases for the modernization of its economy, largely via the building of railways, which represented a huge financial effort.

The relationship between railways and population dynamics has heretofore seen little study. This article shows that railway ac-

1 LINE SHORT

REGULAR

1 LINE LONG 
cess helped to increase population concentration in the areas served by this infrastructure; railways favored the growth of preexisting urban centers and the emergence of new ones. They also encouraged migration into towns, thus contributing to their development, even though the proportion of Portugal's urban population in the I930s was far from outstanding by European standards.

As contemporary critics of Portugal's economic policy during the second half of the nineteenth century affirmed, railways came to benefit the prosperous regions and might have exacerbated the conditions unfavorable to development in areas with greater structural weaknesses. Recent historiography, in studying the spatial redistribution of industry, points to the validity of this idea, which this article reinforces, in relation to the evolution of Portugal's population and its urban centers.

In the Inland North, traditionally affected by greater transportation difficulties, railways seem to have contributed to a decline in population relative to other regions of Portugal. Moreover, this area continued to be characterized by a predominance of modest-sized cities, unable to match the dynamism of the urban centers in the coastal regions or to attract a migrant population to aid in their development. In this respect, the presence of a railway seems to have been a significant factor in the differentiation between regions. 